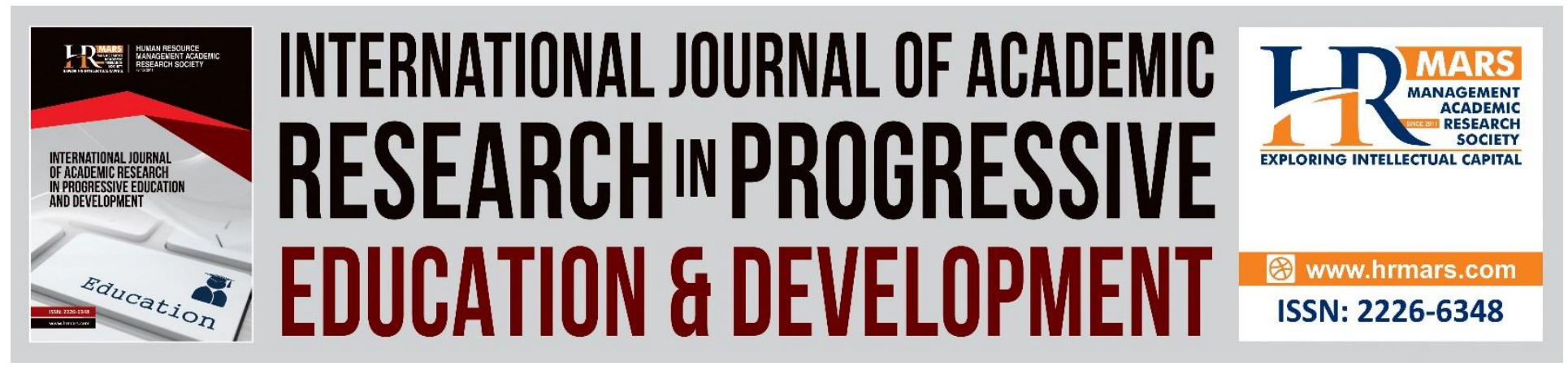

\title{
Interaction Module Development Based on Higher Order Thinking Skills
}

Zaharah Osman, Azizah Zain, Mazlina Che Mustafa

To Link this Article: http://dx.doi.org/10.6007/IJARPED/v10-i2/9727

DOI:10.6007/IJARPED/v10-i2/9727

Received: 06 February 2021, Revised: 10 March 2021, Accepted: 26 March 2021

Published Online: 22 April 2021

In-Text Citation: (Osman et al., 2021)

To Cite this Article: Osman, Z., Zain, A., \& Mustafa, M. C. (2021). Interaction Module Development Based on Higher Order Thinking Skills. International Journal of Academic Research in Progressive Education and Development, 10(2), 100-108.

Copyright: (C) 2021 The Author(s)

Published by Human Resource Management Academic Research Society (www.hrmars.com)

This article is published under the Creative Commons Attribution (CC BY 4.0) license. Anyone may reproduce, distribute, translate and create derivative works of this article (for both commercial and non-commercial purposes), subject to full attribution to the original publication and authors. The full terms of this license may be seen at: http://creativecommons.org/licences/by/4.0/legalcode

Vol. 10(2) 2021, Pg. 100 - 108

http://hrmars.com/index.php/pages/detail/IJARPED

JOURNAL HOMEPAGE

Full Terms \& Conditions of access and use can be found at http://hrmars.com/index.php/pages/detail/publication-ethics 


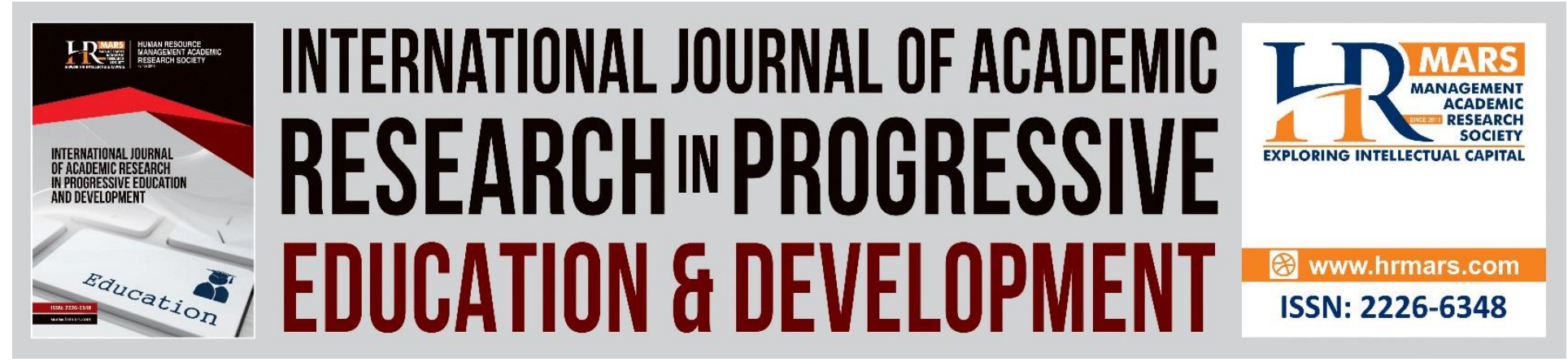

\title{
Interaction Module Development Based on Higher Order Thinking Skills
}

\author{
Zaharah Osman, Azizah Zain, Mazlina Che Mustafa \\ Human Development Faculty, Universiti Pendidikan Sultan Idris, 35900 Tanjung Malim, Perak, \\ Malaysia
}

\begin{abstract}
This research aims to study the development process of learning modules in order to increase the interaction between teachers and children based on Higher Order Thinking Skills (HOTS) in story-telling activities. The development process involves material preparation, expert review, and module content assesment. This module development process employs four experts from different fields. A few suggestions have been identified and improvements were made based on the suggestions given. The revised module is assessed for content accuracy by four evaluators, where two are early childhood education experts and two are kindergarten teachers. There are three aspects that are evaluated, which are module delivery and presentation, module content, and language presentation. Findings show this module has good verified content and meets the targets of the evaluators who are experts in their field, and module target users. Therefore, this module can be used by parents and educators to build knowledge and skills on HOTS which are conducting analysis, giving new ideas, as well as making connections during interactions with children.
\end{abstract}

Keywords: Development, Interaction, HOTS

\section{Introduction}

A child possesses a multitude of characteristics, which influences and can be influenced by their interaction with their closest environment (Bronfenbrenner, 1979). This reciprocating interaction with the environment can influence a child's development. When considering Bronfonbrenner's model in a teaching environment, the main process is the interaction between teacher and children. A teacher must provide learning opportunities to the children and cultivate the child's development academically, cognitively, and well as socially (Vandenbroucke et al., 2018).

Interaction is divided into two stages, which are the proactive and interactive stages (Moore, 1987). The proactive stage is when a teacher objectively chooses and plans a teaching strategy while the interactive stage is when the teacher gives verbal stimulation to the classroom. Educators need to prepare a lesson plan by choosing an objective before starting the teaching 
and learning process. Interactions that can be used by teachers with their students include questions and answers using simple sentences based on stimulus materials. Questions used in the interaction between teachers and students must be high-level based which are application, analyzing, evaluating, and creating (KPM, 2016) to ensure HOTS application can be done from a young age. There are plenty of stimulus materials that can be utilized such as natural materials, storybooks, and others. Moore (1989) also stated that there are three types of interactions, namely interaction between children and lesson content, children with teachers, and children with children. Teachers in the teaching and learning process should use these three interactions.

HOTS is the ability to apply knowledge, skills, and values in reasoning and reflection in problem solving, decision-making, innovating, and the ability to create (KPM, 2016). The HOTS element has been inserted into the Standard National Preschool Curriculum (KPM, 2016), which are application, analysis, evaluation, and creation. Storytelling is a method that can be applied in the classroom. When a teacher tells a story, students listen, query, and ask questions if the story is unclear or if they seek for further explanation. Teachers who tell stories to their students (Lenhart et al., 2018) are able to enrich their teaching or apply additional interactive techniques. Through storytelling, the interaction between teacher and student can reach a high quality if a comfortable relationship between teacher and student exists by effective interactions which is constructive in nature (Gallagher et al., 2013). Children should be taught to use thinking skills creatively, asking questions that can help them to identify items that need to be learned in this fast-changing world (Torrance, 1979).

\section{Problem Statement}

In the teaching and learning process, there is no one specific or best method or strategy to be applied in classrooms that have a variety of students (KPM, 2016). However, teaching approaches and methods that are less effective can cause delayed cognitive development among children (Nachiappan, 2014b). The implementation of questioning method in teaching and learning is able to stimulate one's thought process through various approaches such as direct questioning, group questioning, questioning process, and assesment questions (Mahmud \& Rosli, 2015). According to Mahamod and Lim (2011), teachers are less adept in the questioning technique in the classroom. A teacher who is less adept in the questioning technique can cause the teacher's failure in asking questions to stimulate the student's thinking which will subsequently cause the child to be less involved in the teaching and learning process.

Teachers need readiness to implement HOTS in their lessons. A teacher's readiness and ability in delivering HOTS is still insufficient and the usage of conventional methods in teaching is still widely used among teachers (Nor \& Kamarudin, 2016). This situation leads to students' inability to use their thinking skills optimally, their inability to gain the skills to present questions to teachers or friends, and to choose to stay silent due to anxiety, lack of self-confidence, and shyness. Interactions between teachers and children are an important element to children from a teaching, learning, and evaluating context (Douglas et al., 2015).

Drastic measures by the Malaysian Ministry of Education (2013) to implement HOTS in teaching and learning truly tested the preparedness of the teachers. Exposure should be given to 
the teachers by certain parties so that knowledge relative to HOTS can be imparted to the students. A teacher's knowledge readiness in HOTS is able to conceive ways to increase HOTS in children. To ensure learning happens, Vygotsky (1978) proposed that the interactional language used should be clear and meaningful. HOTS implementation should be in questions when teachers interact with children during storytelling activities. This is because through HOTS interaction between teachers and children during storytelling, children become accustomed to it and ease them when facing everyday problems.

Here lies the teacher's role in cultivating thinking skills in children through interactions using appropriate questions and answers, open questions, encouraging questioning, and praise as encouragement for a teacher's interaction with children (Ali \& Madon, 2014). Teachers need to teach children to retain information, idea and concept clarity, usage of knowledge in new or similar situations in the teaching and learning process. In addition, teachers could also help children to produce important ideas, make considerations and decisions, as well as ponder upon new ideas and ways to use information so that the children may use their thinking skills to the best of their abilities.

\section{Research Objective}

The intended research objective through this research is to develop a learning module to increase interactions between teachers and students based on HOTS in their storytelling activities.

\section{Research Question}

How can the learning modules that increase the interactions between teachers and children based on HOTS in storytelling activities be developed?

\section{Methodology}

Module development involves processes such as module draft building, which was made, based on the needs analysis findings, theory, literature review, and curriculum review. The interaction modules of teachers with children used in storytelling activities comprise of 12 stories and each story contains four questions covering the application, analysis, evaluation, and creation (KPM, 2016). Four experts from different fields examined the module that was produced using an expert review form. Suggestions from the experts were condensed for the purpose of improvement. The verified modules were then distributed to four evaluators, comprising of two experts in the field of early childhood education and two experienced TADIKA teachers to evaluate and verify the accuracy of the module content in terms of the presentation, content, and language presentation.

Module content validity evaluation was done using a module content validity questionnaire which requires the evaluators to provide answers based on a five-point Likert scale, which are: (1) strongly disagree, (2) disagree, (3) unsure, (4) agree, and (5) strongly agree. Data was then analyzed using the module content validity calculation method as suggested by Tuckman and Waheed (1981), whereby an achievement level of 70 percent is considered good module content and have mastered a high level of achievement. 
INTERNATIONAL JOURNAL OF ACADEMIC RESEARCH IN PROGRESSIVE EDUCATION AND

DEVELOPMENT

Vol. 10, No. 2, 2021, E-ISSN: 2226-6348 @ 2021 HRMARS

\section{Research Findings}

This section reports the research findings on the learning module development to increase the interactions between teachers and children based on HOTS.

\section{Learning Module Development to Increase Interactions Between Teachers and Children Based on HOTS}

During the development stage, the module produced is based on the needs analysis findings, theory, literature review, and curriculum review. Information analysis is an important ingredient in producing a module necessary for teachers. In order to produce a comprehensive module, the development process takes into account-combined theories, literature review, and curriculum review. Basically, the module content is formatted into two sections, namely: (1) introduction and explanation on module usage, and (2) 12 storytelling activity suggestions. The first module contains smaller topics aimed to increase the teacher's knowledge on HOTS to ensure that the teacher fully grasps how to implement this module in the lessons. This first section also gives useful information to the teacher in executing good teaching and learning activities. After following and understanding the first section, the teacher may then proceed with the teaching and learning activities in the second section. There are 12 total storytelling activity suggestions that are developed in the form of daily lesson plans. The aim of the second section is to increase the teacher's skill to practice their interactions with children in storytelling activities using HOTS. Every lesson plan contains detailed steps developed based on the theory, standard curriculum, and literature review. The teacher, in order for the student to reach the learning objective, should follow these steps. Every storytelling activity contains questions based on HOTS level. The steps in the activities emphasize on a knowledge-building process through the self-initiative. The duty of the teacher is to guide the learning process and stimulate the children to think. To give a clearer picture of this module, Table 1 shows the format and topic division in the module, which are divided into two sections. 
Table 1: Format and topic division in the module

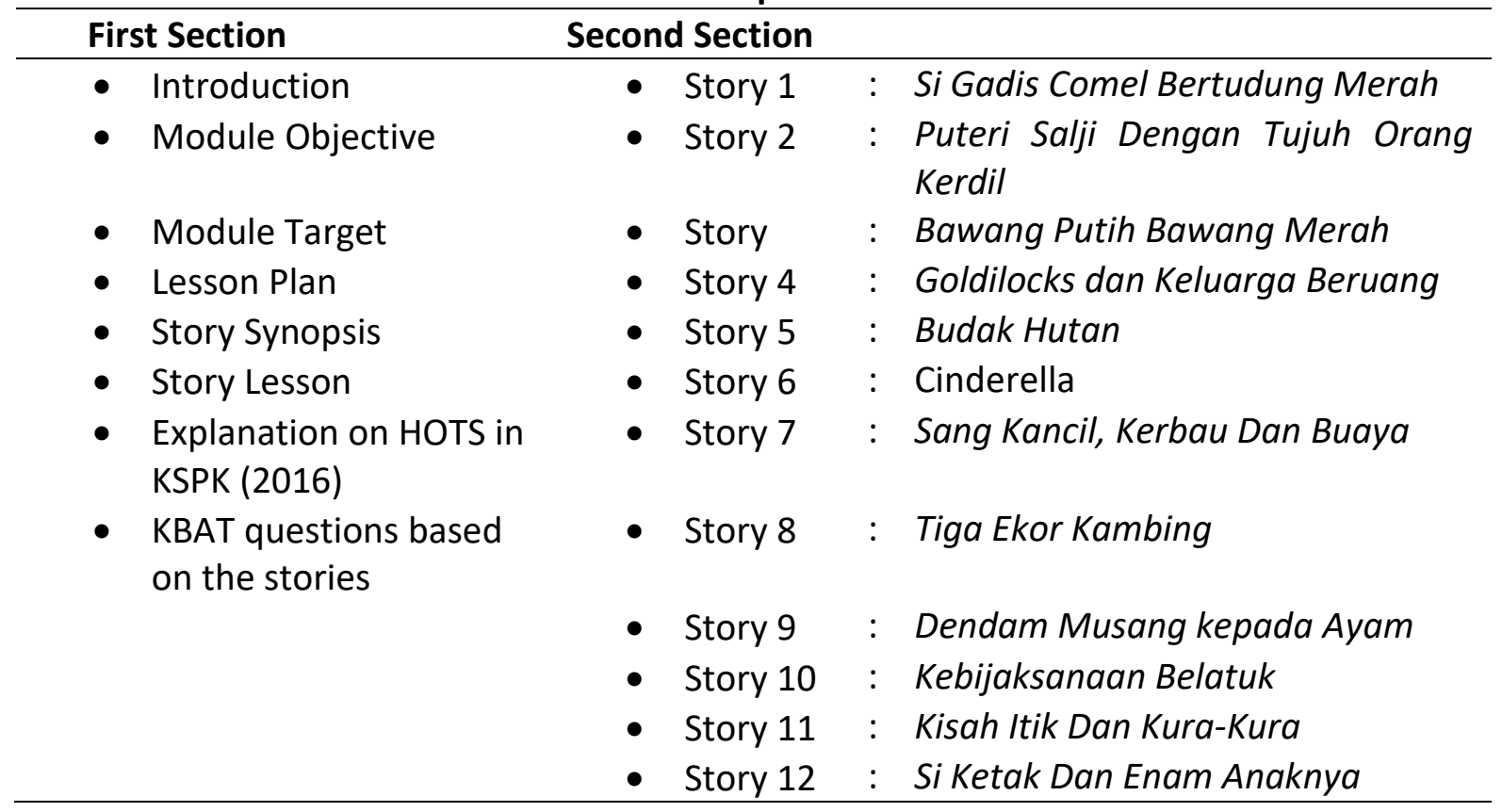

Modules employing HOTS in the storytelling activities through teachers' interactions with children are designed and prepared. Modules are then given to two early childhood education experts and two experienced TADIKA teachers for them to evaluate the accuracy of the module content in order to determine the validity of the module content. Module evaluation is paramount to produce a module that complies with the field of study and is able to be utilized by the user. There are 20 items that encompass three aspects that are rated including delivery and presentation of module, module content, and presentation language. From the aspect of module presentation, 100 percent of evaluators agree that the module's presentation is appropriate for TADIKA teachers and that the module content structure is easy enough for a TADIKA teacher to follow. As for content, 100 percent of evaluators are of the opinion that the suggested questioning activities are able to increase the teacher's knowledge on HOTS and that the suggested HOTS questions are able to increase teachers' interactions with children. Table 2 shows an analysis on the level of evaluation agreement towards the module content. 
INTERNATIONAL JOURNAL OF ACADEMIC RESEARCH IN PROGRESSIVE EDUCATION AND DEVELOPMENT

Vol. 10, No. 2, 2021, E-ISSN: 2226-6348 @ 2021 HRMARS

Table 2: Analysis on the level of evaluation agreement towards module content

\begin{tabular}{|c|c|c|c|c|}
\hline \multicolumn{2}{|c|}{ Aspect/Statement } & \multirow[t]{2}{*}{ Unsure } & \multirow[t]{2}{*}{$\begin{array}{l}(n=4) \\
\text { Agree }\end{array}$} & \multirow[t]{2}{*}{$\begin{array}{l}\text { Strongly } \\
\text { Agree }\end{array}$} \\
\hline No & Delivery and Presentation of Module & & & \\
\hline 1 & Module title is appropriate to module aim. & & $1(25 \%)$ & $3(75 \%)$ \\
\hline 2 & Text used in module is clearly delivered. & & $1(25 \%)$ & $3(75 \%)$ \\
\hline 3 & $\begin{array}{l}\text { Module presentation is appropriate for TADIKA } \\
\text { teachers. }\end{array}$ & & & $4(100 \%)$ \\
\hline 4 & $\begin{array}{l}\text { Module content structure is easy to follow for } \\
\text { TADIKA teachers. }\end{array}$ & & & $4(100 \%)$ \\
\hline 5 & $\begin{array}{l}\text { Pictures in the module are related to the text } \\
\text { written. }\end{array}$ & & & $4(100 \%)$ \\
\hline 6 & Module presentation is user-friendly. & & $2(50 \%)$ & $2(50 \%)$ \\
\hline
\end{tabular}

\section{Module Content}

7 Suggested stories ease teachers' lesson planning.

$4(100 \%)$

8 Based on stories, HOTS question sequence is

$4(100 \%)$ according to level

9 The stories provided create motivation for the student to listen.

10 Suggested activities are able to increase teachers' HOTS knowledge

11 Suggested HOTS question is able to increase the interaction between teachers and children

12 Suggested storytelling activities are able to increase the mastery in listening skills and in giving responses according to children's needs.

13 Activity suggestion is appropriate with children's development level.

14 Activity sequences are delivered neatly

$2(50 \%) \quad 2(50 \%)$

15 Suggested stories are interesting.

$4(100 \%)$

16 Craft activities help teachers perform reinforcing activities with students.

$4(100 \%)$

$4(100 \%)$

$2(50 \%) \quad 2(50 \%)$

$4(100 \%)$

$4(100 \%)$

$4(100 \%)$

\section{Language Presentation}

17 Module writing style is easy to read.

$4(100 \%)$

18 Words used in module are correctly spelled.

$4(100 \%)$

19 Language used in the module is easy to

$4(100 \%)$ understand.

20 Module writing style is appropriate for teachers.

$4(100 \%)$ 
Vol. 10, No. 2, 2021, E-ISSN: 2226-6348 @ 2021 HRMARS

Module is also appraised for its content validity using the module content validity calculation method as suggested by Tuckman and Waheed (1981) whereby they stated that 70 percent is considered as good. Calculation results from the level of achievement of the content module validity by two early childhood education experts and two TADIKA teachers show a percentage value of over 70 percent, which is 94.5 percent. The findings show that this module has good content validity and meets the evaluator's targets that are experts in their field and the target module users. Table 3 shows the analysis data of the module content validity.

Table 3: Analysis data on module content validity.

\begin{tabular}{lll}
\hline Evaluator & Percentage (\%) & Content Validity Level \\
\hline 1 & 97 & Good \\
2 & 96 & Good \\
3 & 90 & Good \\
4 & 95 & Good \\
\hline Overall Total (Min) & 94.5 & Good \\
\hline
\end{tabular}

\section{Conclusion}

This research shows that the development of a learning module based on HOTS in storytelling activities is able to increase the interactions between teachers and children. Though knowledge and skills of HOTS, teachers are able to integrate HOTS elements into their teaching and learning process. Emphasis on HOTS in TADIKA is in line with the Pelan Pembangunan Pendidikan Malaysia (PPPM) 2013-2025 transformation that aims to produce a generation of critical thinkers (KPM, 2013a). The usage of HOTS helps children be more active during interactions with their teachers in their learning process. Healthy interaction in learning activities can produce meaningful learning (Haliza \& Joy, 2016). The interaction process that happens through storytelling activities can help to increase children's ability to analyze, produce ideas, as well as make connections. This research gives important implication to identify alternatives that can be applied by teachers to increase HOTS in children.

\section{Acknowledgement}

This research is conducted with the help of UPSI Research Grants (GPU 2018-0038-107-01). Thank you to UPSI that has granted this research fund and to all parties involved in this research.

\section{Corresponding Author}

Zaharah binti Osman

Department of Early Childhood Education, Universiti Pendidikan Sultan Idris

Email: zaharah@fpm.upsi.edu.my 
INTERNATIONAL JOURNAL OF ACADEMIC RESEARCH IN PROGRESSIVE EDUCATION AND

DEVELOPMENT

Vol. 10, No. 2, 2021, E-ISSN: 2226-6348 @ 2021 HRMARS

\section{References}

Bronfenbrenner, U. (1979). The Ecology of human development: Experiments by nature and design. Cambridge, MA: Harvard University Press.

Douglas, J. A., Douglas, A., McClelland, R. J., \& Davies, J. (2015). Understanding student satisfaction and dissatisfaction: an interpretive study in the UK higher education context. Studies in Higher Education, 40(2), 329-349.

Gallagher, K. C., Kainz, K., Vernon-Feagans, L., \& White, K. M. (2013). Development of Student teacher Relationship in Rural Early Elementary Classrooms. Early Childhood Research Quarterly, 28, 520-528

Kementerian Pendidikan Malaysia. (2013a) Pelan Pembangunan Pendidikan Malaysia

(PPPM) 2013 - 2025 (Pendidikan Prasekolah Hingga Lepas Menengah). Putrajaya

Kementerian Pelajaran Malaysia. (2016). Standard Kurikulum Prasekolah Kebangsaan Malaysia. Kuala Lumpur: Ministry of Education Malaysia

Lenhart, J., Lenhard, W., Vaahtoranta, E., \& Suggate, S. (2018). Incidental vocabulary acquisition from listening to stories: a comparison between read-aloud and free storytelling approaches. Educ. Psychol. 38, 596-616.

Moore, M. G. (1987). University Distance Educations of Adult.Tech Trends, 32 (4), 13-18.

Moore, M. G. (1989). Three types of interaction. The American Journal of Distance Education, 3(2), $1-6$.

Nor, M. N. A. M., \& Kamarudin N. (2016) Penyebatian kemahiran berfikir aras tinggi (KBAT) dalam proses pengajaran dan pembelajaran di Institut 28 Pendidikan Guru (IPG), Malaysian Journal Of Higher Order Thinking Skills In Education, 2, 199-214

Mahmud, M. S., \& Rosli, R. (2015). Penyoalan Lisan Dalam Pengajaran Dan Pembelajaran Matematik: Kajian kes Dua Orang Guru Sekolah Rendah. $5^{\text {th }}$ National Education Seminar Proceeding.

Ali, N., \& Madon, Z. (2014). Tinjauan awal interaksi guru-guru -kanak-kanak dalam pemupukan pemikiran kreatif kanak-kanak prasekolah. , 735-746

Nachiappan, S. (2014b). Panduan Pendidikan Awal Kanak-Kanak: Teori, Model, Kaedah dan Aktiviti ke Arah Perkembangan Kognisi. Tanjong Malim: Universiti Pendidikan Sultan Idris Publisher.

Torrance, E. P. (1979). The Search for Satori and Creativity. New York: Creative Education Foundation.

Tuckman, B. W., Dan Waheed, M. A. (1981). Evaluating An Individualized Science Programme For Community College Student. Journal of Research in Science Teaching 18: 489-495

Vandenbroucke, L., Spilt, J., Verschueren, K., Piccinin, C., Baeyens, D. (2018). The classroom as a developmental context for cognitive development: A meta-analysis on the importance of teacher-student interactions for children's executive functions. Review of Educational Research, 88, 125-164.

Vygotsky, L. S. (1978). Mind in Society: The Development of Higher Mental Process. Cambridge: Harvard University Press.

Mahamod Z., \& Lim, N. R. (2011). Kepelbagaian kaedah penyoalan lisan dalam pengajaran guru bahasa Melayu: Kaedah pemerhatian. Bahasa Melayu Education Journal, 1, 51-65. 